\title{
Assessment of the Nutrient Intake of Undergraduates Attending Polytechnic in Owo, Ondo State, Nigeria.
}

\author{
Folahan O.O ${ }^{1}$ and Odugbemi B. A. ${ }^{2}$ \\ 1 Nutrition and Dietetics Department, Ogun State College of Health Technology, Ilese-Ijebu, Ogun State, \\ Nigeria. \\ 2 Community Health Department, Ogun State College of Health Technology, Ilese-Ijebu, Ogun State, Nigeria.
}

\begin{abstract}
The accompanying challenges of the university or college life cannot be over emphasized as these do affect the eating behaviours of students. The Nutrient intake of female students was studied to assess the adequacy of their dietary intakes. Questionnaires were administered to 217 female undergraduate in Rufus Giwa Polytechnic Owo, using the hostel registers as the simple frame. Majority (74.6\%) of the students admitted that their household heads earn more than $\$ 40000$ and $76.5 \%$ of the respondents was given between $\$ 5000$ to $\$ 10000$ as pocket money. The income of the head of the household affects the average monthly pocket money given to the students. The mean nutrient intake of the respondents was $1656.94 \pm 194 \mathrm{kcal}$ which is $86.5 \%$ recommended daily allowance (RDA). Intakes of protein, zinc, iron and vitamin A were respectively, $102.45 \%$, $109.38 \%, 128.48 \%$ and $233 \%$ of $R D A$ while the intakes of calcium and vitamin $C$ were lower $155.26 \%$ and 10.98 respectively) than $R D A$.
\end{abstract}

Key word: Recommended daily allowance (RDA), nutrient intake, undergraduate, pocket money.

\section{Introduction}

Nutritional status is the balance between the intake of nutrients by an organism and the expenditure of these nutrients in the processes of growth, reproduction and health maintenance. Because this process is quite highly individualised, nutritional status can be directed at a wide variety of aspects of nutrition. These ranges from nutrient levels in the body to the products of their metabolism and to the functional processes they regulate Nutritional status is the combination of an individual's health as influenced by intake and utilisation of nutrients and determined from information obtained by physical, biochemical and dietary studies (1).

Studies have shown that disturbed eating behaviour exists among female students and this jeopardizes their nutritional status (2). Needless to say that poor nutritional practices, heightened levels of stress, which are two common attributes of university life which are strongly linked with decreased health (3).

In addition to the stress of University life, the diet of the average tertiary student is inadequate, meals are often skipped by students in management of weight and average poor eating behaviour is due to the price of unhealthy food; easy access to fast food consumption which is significantly related to lower physical activity levels and higher expenditure for food on campus (3) and most of their food intake are not healthy, this is due to the easy access to fast food.

When students first enter college, their diet often deteriorates and they often gain weight and the weight gain may be related to sedentary life style , changes in food intake and the dietary patterns. However, irregular class schedule, part time jobs and varied home work loads can disrupt eating pattern among students, leading to unhealthy habits which may be hard to break (4). Hence, this study assessed the nutrient intake of polytechnic student in Ondo State, Nigeria.

\section{Subjects and Methods}

This study was a random survey of female polytechnic students in Owo, Ondo State, between January 2012 and March 2012. A total of two hundred (217) Female undergraduate students were systematically sampled and recruited for the study using the hostel register as the sample frame. Pretested semi-structured questionnaire was used to elicit information on socio economic status; 24-hour dietary recall protocol was used to assess the nutrient intake of the students (7). Data collected was analyzed using Statistical Package for Social Sciences (SPSS) version 17 and nutri-survey software was used to analyse the nutrient intake of the respondents and compare with Recommended Daily Allowance (RDA).

\section{Results}

Table 1 shows that $2.3 \%, 2.3 \%, 2.8 \%, 17.8 \%, 29.1 \%$ and $45.5 \%$ of the heads of household earned less than 10000 naira, between 10000 - 19999 naira, N20000 - 29999, 30000 - 39999, 40000 - 49999 and more than 50000 respectively. 
Assessment Of The Nutrient Intake Of Undergraduates Attending Polytechnic In Owo, Ondo State,

TABLE 1 Income Status

\begin{tabular}{lll}
\hline Head of household's income (A) & No & \% \\
\hline Less than 10000 & 5 & $2.3 \%$ \\
$1000-19999$ & 5 & $2.3 \%$ \\
$20000-29999$ & 6 & $2.8 \%$ \\
$30000-39999$ & 38 & $17.8 \%$ \\
$40000-49999$ & 62 & $29.1 \%$ \\
More than 50000 & 97 & $45.5 \%$ \\
\hline
\end{tabular}

Table 2 reveals that $13.8 \%$ of the students receive less than $\$ 5000$ as their average monthly pocket money, $76.5 \%, 7.4 \%$ and $2.3 \%$ receives $\$ 5000$ - $\$ 9999$, 10000 - 19999 and more than $\$ 20000$ respectively.

Table 2 The Pocket Money of the Respondents

\begin{tabular}{lll}
\hline Average Monthly Pocket Money (\#) & No & \% \\
\hline Less than 5000 & 30 & $13.8 \%$ \\
$5000-9999$ & 166 & $76.5 \%$ \\
$10000-19999$ & 16 & $7.4 \%$ \\
More than 20000 & 5 & $2.3 \%$ \\
\hline
\end{tabular}

Table 3 shows that the income of head of household determines the average monthly money received by students as majority that gave their wards more than $\$ 5000$ earns more than $\$ 40000$ per month.

TABLE 3 the Relationship between the Head of Household's Income and the Average Monthly Pocket Money of the Students

\begin{tabular}{|c|c|c|c|c|c|c|c|c|}
\hline \multirow{3}{*}{$\begin{array}{l}\text { Head of Household's } \\
\text { Income ( }\end{array}$} & \multicolumn{8}{|c|}{ Average Monthly Pocket Money (A) } \\
\hline & \multicolumn{2}{|c|}{$<5000$} & \multicolumn{2}{|c|}{$5000-9999$} & \multicolumn{2}{|c|}{$10000-19999$} & \multicolumn{2}{|c|}{$>20000$} \\
\hline & No & $\%$ & No & $\%$ & No & $\%$ & No & $\%$ \\
\hline$<10000$ & 5 & 17.9 & 0 & 0 & 0 & 0 & 0 & 0 \\
\hline $10000-19999$ & 1 & 3.6 & 4 & 2.4 & 0 & 0 & 0 & 0 \\
\hline $20000-29999$ & 3 & 10.7 & 3 & 1.8 & 0 & 0 & 0 & 0 \\
\hline $30000-39999$ & 9 & 32.1 & 26 & 15.9 & 2 & 12.4 & 1 & 20 \\
\hline $40000-49999$ & 4 & 14.3 & 56 & 34.1 & 1 & 6.3 & 1 & 20 \\
\hline$>50000$ & 6 & 21.4 & 75 & 45.7 & 13 & 81.3 & 3 & 60 \\
\hline Total & 28 & 100 & 164 & 100 & 16 & 100 & 5 & 100 \\
\hline
\end{tabular}

Table 4 shows that energy, vitamin and Calcium intakes of the respondents were respectively lower than RDA $(86.5 \%, 10.98 \%$ and $55.26 \%)$, while the optimum levels $(102.5 \%, 109.38 \%$ and $128.48 \%)$ of protein. zinc and iron intake were respectively attained.

TABLE 4 Mean nutrient intake of the respondents

\begin{tabular}{llll}
\hline NUTRIENTS & AMOUNT & ${ }^{*}$ RDA & \%RDA \\
\hline Energy(K/Cal) & 1656.94 & 1936 & 86.5 \\
CHO (g) & 275.66 & 290.4 & 95 \\
Protein (g) & 50.48 & 48.8 & 102.45 \\
Fat (g) & 39.16 & 64.53 & 60.68 \\
Vitamin A (IU) & 11686 & 500 & 233 \\
Vitamin C (mg) & 3.295 & 30 & 10.98 \\
Zinc (mg) & 7.11 & 6.500 & 109.38 \\
Iron (mg) & 16.06 & 12.500 & 128.48 \\
Calcium (mg) & 248.7 & 450 & 55.26 \\
\hline
\end{tabular}

\section{Discussion}

The effect of socio-economic status on the food consumption and nutritional status cannot be over emphasized because poverty is a root cause of undernourishment and malnutrition as $74.6 \%$ of the respondents admitted the head of their households earned more than N40000 per month. The study also showed that income levels determine the pocket money given to the students and seen in table 2 . This agrees with the findings of Parizková(2000)(5) who said that In the countries and /or areas with sufficient income, economic access to food is too abundant when considering the real needs of an individual, especially from the point of view of energy intake and output. In particular, previous studies have identified income levels as key determinants of child malnutrition $(6,7)$.

The assessment of nutrient intake of the subjects using $24 \mathrm{hrs}$ dietary recall showed that the mean intake of the nutrient was slightly lower than Recommended Dietary Allowance (RDA), as intake was 86\% of RDA. This might be due to a very tight working schedules common with undergraduates which can affect healthy eating pattern. This low nutrient intake agrees with study that showed that low nutrient intake is due to skipping of meals, management of weight and food intake, changes in class and work schedules, life style changes, peer pressure, limited finance and access to food (8). This study also agree with Ijarotimi (2004)(9) in the study conducted among young girls who reported that none of the subjects was able to meet energy requirements 
when mean values of energy intake of the subjects was compared with RDA. However, some studies differed in their report that the energy intake was higher than the FAO/WHO requirements in all the schools studied $(10,11)$.

The study showed low calcium and Vitamin $\mathrm{C}$ intakes this correlates with the findings of Parizková(2000)(5) who found out that the composition of the diet among the group studied was not adequate, i.e. too much protein, fats, sugar etc. he also said that the situation is similar to that in Western countries, USA etc. On the other hand, adolescents in Central and Eastern Europe consume too few vegetables, fruit and milk products in their diet (i.e. low intakes of $\mathrm{Ca}$, fibre and vitamin $\mathrm{C}$. The findings agreed with others findings, which established that besides protein and energy malnutrition, deficiencies of micronutrients are more pronounced among the pregnant women, young children and adolescents in developing countries $(9,12,13)$. Although the intake of iron was found to be optimal but the bio-availability was not ascertained since most of these was got from plant sources and adequate intake of Vitamin $\mathrm{C}$ is required to improve the absorption of dietary iron therefore, careful meal planning is required to maximize adolescents iron consumption(14). Also, the vitamin A consumption of the students were higher than the daily requirement this must be due to adequate consumption of vegetables, palm oil and fortified oil that are rich in beta carotene. This finding correlate with those of Ijarotimi, (2004)(9) who found out that the intake of fruits and vegetables help adolescents meet the requirements for Vitamin $\mathrm{A}$.

A related study showed that college students have little variety in their diet and often turn to high snacks. They barely have time for themselves because college life is also a period during which individuals are for the most part exposed to stress and lack of time, posing a barrier to adoption of healthy practices (15). Anyika et al(10) equally reported in 2009 that; the adolescents in secondary school and university girls in their study adopted a "grazing" pattern of eating which is characterized by small meals at frequent intervals or a series of snacks. The poor nutrient intake also goes in agreement with what Dirskell et al, (2006)(3) says that poor nutritional practice, heightened levels of stress, two common attribute of university life are strongly linked with weight gained and decreased health. When people skip meals or drastically reduce their food consumption on a daily basis, they may end up with more problem than they bargained for (decreased metabolism and nutritional deficiencies).

\section{Conclusion}

The study showed that the nutrient intakes of the respondents were not optimal as intakes were observed to be lower than RDA. This could be attributed to skipping of meals, irregular class schedules and varied home work loads which disrupts eating pattern among students. This low caloric intake restricted the amount of vitamin and minerals, the body needs for healthy and optimal function.

\section{Recommendations}

Nutrition education should be added to the curriculum of tertiary education to adequately educate students on healthy dietary practices and Vendors should improve access to low cost healthy local foods especially fruits (i.e. banana, pawpaw, pineapple, oranges, pears, carrots, maize combs, eggs, homemade yoghurt, enriched gruel with fruits and groundnuts) and decrease access to junk food in schools.

\section{References}

[1]. Durning, J.V. and Fidanza F. (1985): Evaluation of Nutrition Status Biblthca Nutri. Dieta 35:20-30

[2]. National Centre Biotechnology Information, (NCBI): US, National Library of Medicine of Health (2011).

[3]. Dirskell et al (2006): Nutritional Practices among College Students. "McGraw-Hill". London p.322

[4]. Haverman et al (2003): Food Choice, $2^{\text {nd }}$ Ed. Oxford University Press (2003) pg 267-301

[5]. Parizková, J.(2000). Dietary habits and nutritional status in adolescents in Central and Eastern Europe. European Journal of Clinical Nutrition (54) 1, 336-340

[6]. Food and Agriculture Organisation (2000). The Sate of Food Insecurity in theWworld. FAO for the UN. Rome, Italy.

[7]. Maxiya-Dixon, B., Oguntona, E. B., Harris, E., Nokoe, S., Manyong, V., Akinyele. I. O. and Sanusi, R. A. (2004). Nigeria food consumption and nutrition survey 2001-2003. Food Instruction Booklet. Ibadan, Nigeria. 62-64pp.

[8]. Elizabeth, B. (1979): "Influences on Food Choices": $4^{\text {th }}$ Ed. The CV Mosby Company, et Louis p.504

[9]. ljarotimi, OS, Eleyinmi, A F, and Ifesan, OT. 2003. Evaluation of nutritional status of adolescents in institutionalized secondary schools in Akure, Nigeria J.of food, agriculture \& environment. I (3\&4):64-68

[10]. Anyika J. U., Uwaegbute, A. C., Olojede, A. O.Nwamara J. U. 2009. Nutrient Intakes of Adolescent Girls in Secondary Schools andUniversities in Abia State of Nigeria. Pakistan Journal of Nutrition 8 (10): 1596-1602.

[11]. Dushi, Irena and Webb, Anthony. 2004. Household Annuitization Decisions: Simulation and Empirical Analyses. Journal of Pension Economy and finance (3) 109-143.

[12]. Bhaskaram, P. 2001. Immunobioogy and mild micronutrient deficiencies. British Journal of Nutrition, 85,pp S75-S80.

[13]. Maharaj, K. B. Bhandari, N. 2003. Management of Severely Malnourished Child; perspectivefrom developing Countries. BMJ 326:146

[14]. Canfield, L.M., Kaminsky, R.G., Taren, D.L., Shaw, E., Sander, J.K. 2001. Red palm oil in the maternal diet increases pro-vitamin A carotenoids in breast milk and serum of the mother-infant dyad. Eur J Nutr. 40(1):30-8.

[15]. Sakamaiki et al (2001): Feeding Habit. A Nutritional Survey. Gerantol. Soc. Amer. M145-M150 